Б. А. Мінькович, аспірант

(Житомирський державний університет імені Івана Франка) b.a.minkovych@gmail.com

ORCID: $0000-0002-6720-0854$

\title{
РОЗВИТОК КРЕАТИВНОСТІ МАЙБУТНЬОГО ВЧИТЕЛЯ ІНФОРМАТИКИ ЗАСОБАМИ ІНФОРМАЦЙНО-КОМУНІКАЦЙНИХ ТЕХНОЛОГІЙ
}

У статті проаналізовано стан розвитку креативного мислення майбутніх учителів інформатики.

Розглянуто вплив інноваційних інформаційно-комунікаційних технологій на успішність творчого розвитку та саморозвитку вчителя. Розкрито сутність поняття "креативність", його основні ознаки, значення розвитку креативності майбутнього вчителя інформатики у практичній діяльності, досвід підготовки вчителя до використання IКТ в старшій школі.

\section{Ключові слова: креативність, креативне мислення, інновації, інформаџійно-комунікаційні технологї.}

Постановка проблеми. В умовах реформування вищої освіти України відповідно до вимог Болонської конвенції, першочергової значущості набуває необхідність осмислення особливостей розвитку педагогічної освіти в Україні як складової європейського освітнього простору. Особливої актуальності набувають проблеми удосконалення підготовки учителів, розвитку їх креативності, що наголошено не лише у вітчизняних нормативних документах розвитку освіти (Державна національна програма "Освіта" ("Україна XXI столітт"), Закон України "Про вищу освіту") але й у декларації Всесвітньої конференції з вищої освіти ЮНЕСКО "Вища освіта у ХХІ столітті: бачення та дії". Радою ЄС креативний підхід до професійної підготовки вчителя розглядається як інноваційний підхід до навчання у системі педагогічної освіти.

У сучасних умовах вчитель повинен володіти здатністю до творчого мислення та інноваційної діяльності, самостійності й нестандартності рішень, інтелектуальної компетентності. Оскільки від вчителя значною мірою залежить якість системи загальної середньої освіти.

В умовах інформатизації суспільства особлива роль належить учителю інформатики, який має володіти не лише творчим мисленням та здатністю до інноваційної діяльності, а й навчити учнів користуватися ІКТ, що зумовлює актуальність та доцільність дослідження в аспекті пошуку ефективних і дієвих форм та методів, сучасних технологій розвитку творчих здібностей, креативного мислення, творчого потенціалу вчителя.

Аналіз останніх досліджень і публікацій. Підгрунтям сучасного розуміння педагогічної креативності, як основи професійної підготовки є науково-теоретичні ідеї С. Вітвицької, О. Антонової, Н. Березанської, Ю. Зіньковського, В. Кан-Каліка, Н. Кічук, Т. Любарта, В. Нуркова, С. Сисоєвої, Р. Стернберга, Л. Хомич та інших.

Дослідженню проблеми креативності присвятили свої праці такі вітчизняні вчені, як: В. Козменко, М. Гнатко, В. Дружинін та С. Медник, а також вчені зарубіжних країн - Дж. Гілфорд, Ф. Бардон, Д. Богоявленська. Видатні дослідники П. Едвардс, К. Роджерс і Л. Виготський доклали багато зусиль у розвиток проблеми, що стосується творчого зростання особистості.

Метою цієї статті, як складової нашого наукового педагогічного дослідження, є визначення ролі і місця інформаційно-комунікаційних технологій у розвитку креативності майбутніх вчителів інформатики.

Виклад основного матеріалу. Розглянувши концепції креативності видатних дослідників Д. Богоявленської та Дж. Гілфорда, можна констатувати, що креативність - це загальна особливість педагога, яка ефективно діє на творчу продуктивність особистості у будь-якій формі прояву його активності.

Дж. Гілфорд у своїх працях стверджує, що "креативність - це процес дивергентного мислення".

Креативність - здатність людини творити незвичайні ідеї, відхилятися від традиційних схем мислення, швидко розв'язувати проблемні ситуації [1].

Учений включає до структури креативності не тільки дивергентне мислення, але й здатність до перетворень, точність розв'язку та інші інтелектуальні параметри, визначаючи позитивний зв'язок між інтелектом і креативністю.

Дж. Гілфорд виділив у власному дослідженні параметри креативності вчителя:

- володіння гнучким та оригінальним мисленням;

- здатність до генерування необмеженої кількості ідей;

- вміння удосконалювати об'єкти з додаванням певних елементів;

- вміння не тільки знайти та поставити проблеми, а й здатність розв'язати їх, використовуючи різні методи; 
- здатність до аналізу та синтезу.

Вчений виокремлює як один із аспектів креативності - креативне мислення, що характеризується створенням суб'єктивно нового продукту та новоутвореннями в самій пізнавальній діяльності. Новоутворення стосуються мотивації, мети, оцінювання. В наукових джерелах подаються вимоги до цього виду мислення. Т. Лубарт та Р.Стернберг виокремлюють такі основні умови до процесу креативного мислення, спрямованого на будь-яку проблему:

- неперервне знаходження та постановка проблем;

- внутрішнє напруження у творчому процесі;

- використання знань і досвіду для створення чогось нового та оригінального;

- постійна зміна уявлень та зовнішньої інформації методом проведення аналогічних дій.

Учені стверджують, що для активізації креативного мислення необхідно створити особливий психічний стан. 3 отриманого досвіду креативність $є$ основним компонентом творчого потенціалу людини, а також пов'язана з властивостями особистості. Тому цей елемент впливає значною мірою на рівень розвитку творчого педагога та його самореалізацію.

Українські вчені розглядають креативність як рису особистості, яка виявляється у гнучкості та конструктивності реагування на організаційні проблеми, здатності приймати нестандартні рішення в ситуаціях невизначеності й неповної інформації, з якими стикається сучасний фахівець.

С. Вітвицька розглядає креативність мислення як складову творчих можливостей майбутніх учителів. На їі думку, творчі можливості - це система інтелектуально-творчих якостей особистості, які сприяють успіху у творчій діяльності. Вона складається з таких підсистем:

- підсистеми спрямованості (мотиви, інтерес, потреби);

- підсистеми характерологічних особливостей особистості (цілеспрямованість, працездатність, сумлінність тощо);

- підсистеми здібностей (індивідуальних особливостей творчих процесів);

- підсистеми творчих умінь.

Необхідними індивідуально-творчими якостями майбутнього дослідника є:

1. Креативність мислення, тобто здатність продукувати нові ідеї, гіпотези, способи вираження проблемних задач.

2. Інтуїція. Пряме бачення суті речей, знаходження правильного вирішення проблеми без усвідомлення шляхів і способів досягнення.

3. Творча уява. Самостійне створення нових образів, які реалізуються в оригінальних і цінних результатах діяльності.

4. Дивергентність мислення. Альтернативність, здатність запропонувати декілька підходів до розв'язання задачі та міняти їх, бачити проблеми, об'єкти в різних ракурсах.

5. Оригінальність мислення, тобто своєрідність якостей розуму, способу розумової діяльності, здатність створювати думки, що відрізняються від загально прийнятих поглядів.

6. Асоціативність мислення. Здатність використовувати асоціації, в тому числі аналогії, а також віддаленість асоціацій.

7. Інтелектуальна активність. Це інтегральний пізнавально-мотиваційний показник рівня розвитку творчої особистості, що базується на інтелектуальній ініціативі".

Інтелектуальна ініціатива - це не стимулювання продовження мислення, це продовження розумової діяльності за межами заданої ситуації, що не обумовлена ні практичними потребами, ні негативною оцінкою роботи [2: 207-208].

Швидкість, оригінальність та гнучкість мислення є основними функціями формування креативного педагога у процесі творчої навчально-виховної роботи з учнями.

Швидкість мислення - це здатність до створення нових ідей, миттєвого переключення між цими ідеями; вміння швидко реагувати на неочікувані складні ситуації.

Оригінальність мислення вчителя проявляється у не стандартному та правильному виборі форми, змісту та методів навчання учнів.

Гнучкість мислення виражається в умінні педагога зацікавити учнів, мотивувати їх до навчання, знайти підхід до кожного з них, виділивши їх індивідуальні особливості.

Креативній особистості вчителя, зокрема вчителя інформатики, мають бути притаманним постійний пошук оптимальних, оригінальних рішень поставлених завдань, творчий стиль мислення, здатність побачити педагогічну проблему і відшукати можливі шляхи іiі розв'язання, творча фантазія, розвинена уява, високий рівень загальної культури, високий рівень моральної свідомості. Творча особистість майбутнього педагога характеризується високим рівнем креативності, яскраво вираженими особистісними якостями та здібностями, що сприятимуть успішній професійній діяльності [3: 12].

О. Антонова розробила основні параметри, які характеризують педагогічну креативність:

- здатність до здійснення творчого підходу у педагогічній діяльності;

- здатність постійно розвивати творчий педагогічний досвід, компетентність; 
- здатність формувати та реалізувати творчу стратегію педагогічної діяльності [4].

На сьогодні ученими визначено рівні творчої педагогічної діяльності, зокрема С. Сисоєвою визначено чотири рівні: репродуктивний; раціоналізаторський; конструкторський; новаторський.

Репродуктивний рівень передбачає діяльність вчителя на основі відомих методик, рекомендацій, досвіду, відбір найбільш відповідних конкретним умовам праці, рівню розвитку творчих можливостей учнів.

Раціоналізаторський рівень передбачає внесення вчителем коректив до своєї роботи, удосконалення, модернізацію існуючих рекомендацій, методик на основі аналізу власного досвіду, конкретних умов своєї педагогічної діяльності, творчих можливостей учнів.

Конструкторському рівню відповідає діяльність учителя 3 конструювання власного варіанту вирішення педагогічної проблеми на основі самоаналізу своєї діяльності і знань творчих можливостей учнівського колективу, але з використанням відомих методик, рекомендацій тощо.

Новаторський рівень передбачає, що вчитель вирішує педагогічні проблеми на принципово нових засадах, які відрізняються оригінальністю, високою результативністю [5].

На основі дослідження і виділених ознак рівнів діяльності вчителів С. Сисоєвою, нами було проаналізовано діяльність 40 учителів інформатики Житомирської області, що дало можливість отримати такі результати:

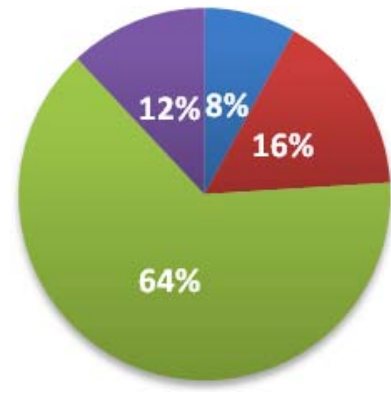

Репродуктивний

- Раціоналізаторський

Конструктивний

Новаторський

\section{Рис. 1. Рівні креативності вчителів інформатики}

- на репродуктивному рівні знаходяться 56 \% учителів;

- $\quad$ на раціоналізаторському - $24 \%$;

- $\quad$ на конструктивному - $12 \%$;

- $\quad$ на новаторському $-8 \%$.

Результати дослідження засвідчують, що більшість вчителів інформатики знаходяться на нижчих рівнях креативності репродуктивному і раціоналізаторському.

Аналіз досвіду викладачів вищих навчальних закладів і власний досвід засвідчує, що для розвитку творчих здібностей майбутніх учителів інформатики потрібно використовувати евристичні методи, які активно стимулюють розвиток їх творчого потенціалу та сприяють формуванню їніх креативних якостей. До таких методів належать: метод аглютинації, мозковий штурм, метод синектики, метод проектів, метод Дельфі, методика "теорії розв’язання винахідницьких завдань".

Метод аглютинації призначений для формування вміння особистості поєднувати між собою несумісні частини, властивості та якості об'єктів. Впровадження цього методу допомагає розвивати уяву, фантазію та здатність до генерування сміливих ідей і гіпотез. Використання методу аглютинації $\epsilon$ найбільш ефективним на уроці інформатики у процесі проведення практичного заняття.

Мозковий штурм є найпопулярнішим методом колективного вирішення будь-якої проблеми, де у процесі обговорення учасниками пропонується висловити максимальну кількість ідей ії розв'язання. Основне завдання полягає у виборі із загальної кількості ідей, запропонованих учасниками, найбільш вдалих, які можна реалізувати на практиці. Метод корисно використовувати у процесі проведення практичних та лабораторних робіт з інформатики у невеликих групах, де кожен буде мати можливість запропонувати власну ідею щодо вирішення проблеми та вдалої іiі реалізації.

Метод синектики - один із оригінальних способів, який застосовується для пошуку нових ідей 3 використанням аналогій та перенесенням поставлених завдань на готові вирішення, які вже існують в іншій галузі. Цей метод грунтується на асоціації та методі мозкового штурму. На початковому етапі обговорюються основні ознаки проблеми, можливі варіанти її розв'язання. Далі пропонуються аналогії 3 інших сфер, які можна використати для вирішення завдання. Цей метод також доцільно застосовувати на практичних заняттях, де відбувається повна активізація учнів у процесі вивчення інформатики.

Метод проектів - це технологія, яка допомагає включити та підвищити активність пізнавальної діяльності особистості у навчально-виховному процесі. Під час виконання практичних завдань (проектів) відбувається накопичення знань та закріплення навичок. Мета проектної роботи полягає у стимулюванні 
особистості до самостійної діяльності: плануванні, організації та контролі. Цей метод допомагає сформувати вміння ефективного використання інформаційно-комунікаційних технологій.

Метод Дельфi або метод експертних оиінок - спосіб швидкого пошуку вирішення проблеми за допомогою інтерв'ю, опитувань та мозкових штурмів, який дозволяє отримати максимального сходження думок експертів для вибору кращого розв'язку завдання. Цей метод перешкоджає відкритого зіткнення між експертами 3 протилежними поглядами, оскільки виключає безпосередній контакт між ними. За принципами методу Дельфі можна вдало оцінити ситуацію та передбачити результат незалежними експертами [6].

Теорія розв'язання винахідницьких завдань $є$ технологією моделювання для створення нових інноваційних ідей та розв'язання будь-яких проблем. Технологія сприяє ефективному розвитку творчої особистості та допомагає їй досягнути високого рівня креативності. На відміну від методики мозкового штурму, де формулюються ідеї й варіанти розв'язання проблеми, метою ТРВЗ є створення чіткого алгоритмічного підходу до винаходу нової системи або поліпшення старої. Тому потрібно приділяти увагу теорії розв'язання винахідницьких завдань для розвитку креативних здібностей вчителя інформатики, оскільки рівень розвитку алгоритмічного мислення $є$ одним із показників формування креативного потенціалу.

Результати дослідження засвідчують, що стимулювання креативного мислення сприяють інформаційно-комунікаційні технології, оскільки ІКТ дозволяють:

- користувачам вносити зміни, випробовувати альтернативи, відстежувати розвиток ідей;

- переадресувати виконання сортування, перетворення, відображення інформації, що надає можливість користувачам читати, спостерігати, розпитувати, інтерпретувати, аналізувати і синтезувати інформацію на вищих рівнях;

- надає можливість забезпечити зворотній зв'язок, залучити користувачів різних рівнів;

- надає доступ до величезних масивів інформації на місцевому та глобальному рівнях у різних часових поясах і географічних точках.

Таким чином, інформаційно-комунікаційні технології мають великий потенціал для розвитку креативності майбутніх учителів, оскільки:

- забезпечують унікальні види діяльності (можлива більш потужна обробка даних та моделювання реальних ситуацій, з'являється доступ до широкого спектру ресурсів, комунікації);

- змінюють відносини між викладачем та студентом (індивідуалізм особистості посилюється, що спонукає його управління власним навчанням, а це і $є$ однією 3 ключових особливостей творчої особистості);

- $\quad$ за допомогою моделювання та зворотного зв'язку створюється середовища, в якому прийняття ризику може бути позитивним досвідом.

Формування й розвиток креативності вчителів інформатики відбувається протягом життя, починаючи з навчання в профільній школі і закінчуючи періодичним навчанням на курсах підвищення кваліфікації в інститутах післядипломної педагогічної освіти [7].

Висновки. Отже, розвитку креативного мислення майбутнього вчителя інформатики сприяє застосування сучасних інформаційно-комунікаційних технологій та методик викладання у процесі вивчення курсу інформатики; врахування змін, які відбуваються у сучасному інформаційному суспільстві та врахування зарубіжного досвіду. Підготовка креативного вчителя, формування покоління вчителів нової генерації, здатних до навчання креативних дітей, є вимогою сучасного інформаційного суспільства.

Перспективи подальших досліджень. Проблемою подальшого дослідження можуть бути розробка методичних рекомендацій щодо підвищення рівня творчої педагогічної діяльності вчителя інформатики.

\section{СПИСОК ВИКОРИСТАНИХ ДЖЕРЕЛ ТА ЛІТЕРАТУРИ}

1. Гилфорд Дж. Три стороны интеллекта / Дж. Гилфорд; пер. с англ. Э. А. Голубевой // Психология мышления : [зб. / ред. А. М. Матюшкин]. - М. : Прогресс, 1965. - С. 443-456.

2. Вітвицька С. С. Основи педагогіки вищої школи : [методичний посібник для студентів магістратури]. - К. : Центр навчальної літератури, 2003. - 315 с.

3. Богоявленская Д. Б. Интеллектуальная активность как проблема творчества / Д. Б. Богоявленская. - Ростов : РГУ, 1983. - $176 \mathrm{c}$.

4. Антонова О. С. Педагогічна креативність у структурі педагогічної обдарованості вчителя / О. С. Антонова // Нові технології навчання : [наук.-метод. зб. Ін-ту інноваційних технологій і змісту освіти МОНМС України, Академія міжнародного співробітництва 3 креативної педагогіки]. - У 2-х ч. - Київ-Вінниця, 2011. - Вип. 69. - Ч. 2. - С. 11-17.

5. Сисоєва С. О. Основи педагогічної творчості : [підручник]. - К. : Мілені, ум, 2006. - 344 с.

6. Овчаров С. М. Індивідуально-креативний підхід у неперервній професійній підготовці вчителів інформатики [Текст] / С. М. Овчаров // Science and Education a New Dimension : Pedagogy and Psychology. - 2013. - Vol. 7. - P. $150-154$ 
7. Овчаров С. М. Основоположні принципи розвитку креативності майбутніх учителів // Теоретичні i прикладні аспекти розвитку креативної освіти у вищій школі : [монографія] / за ред. О. А. Дубасенюк. Житомир : Вид-во ЖДУ ім. І. Франка, 2012. - 284 с.

\section{REFERENCES (TRASLATED \& TRANSLITERATED)}

1. Gilford Dzh. Tri storony intellekta [Three Sides of the Intellect] / Dzh. Gilford; per. s angl. E. A. Golubevoi // Psikhologiia mishleniia [Psychology of Thinking]: [zb./ red. A. M. Matiushkin]. - M. : Progress, 1965. - S. 443456.

2. Vitvytska S. S. Osnovy pedahohiky vyshchoi shkoly [Fundamentals of Higher Education Pedagogy] : [metodychnyi posibnyk dlia studentiv mahistratury]. - K. : Tsentr navchal'noi literatury, 2003. $-315 \mathrm{~s}$.

3. Bogoiavlenskaia D. B. Intellektualnaia aktivnost' kak problema tvorchestva [Intellectual Work as a Creativity Problem] / D. B. Bogoiavlenskaia. - Rostov : RGU, 1983. - 176 s.

4. Antonova O. Ye. Pedahohichna kreatyvnist' u strukturi pedahohichnoi obdarovanosti vchytelia [Pedagogical Creativity in the Structure of the Pedagogical Talent of the Teacher]/O. Ye. Antonova// Novi tekhnolohii navchannia [New Teaching Techniques]: [nauk.-metod. zb. In-tu innovatsiinykh tekhnolohii i zmistu osvity MONMS Ukrainy, Akademiia mizhnarodnoho spivrobitnytstva z kreatyvnoi pedahohiky]. - U 2-kh ch. - KyivVinnytsia, 2011. - Vyp. 69. - Ch. 2. - S. 11-17.

5. Sysoieva S. O. Osnovy pedahohichnoi tvorchosti [Fundamentals of Pedagogical Creativity] : [pidruchnyk]. - K. : Mileni, um, 2006. $-344 \mathrm{~s}$.

6. Ovcharov S. M. Indyvidual'no-kreatyvnyi pidkhid u neperervnii profesiinii pidhotovtsi vchyteliv informatyky [Individual and Creative Approaches to Continuous Vocational Training of Information Science Teachers]/ S. M. Ovcharov // Science and Education a New Dimension : Pedagogy and Psychology. - 2013. - Vol. 7. - P. 150154.

7. Ovcharov S. M. Osnovopolozhni pryntsypy rozvytku kreatyvnosti maibutnikh uchyteliv [Fundamental Principles of Creativity Development of Future Teachers]// Teoretychni i prykladni aspekty rozvytku kreatyvnoi osvity u vyshchii shkoli [Theoretical and Applied Aspects of the Development of Creative Education in Higher Education] : [monohrafiia] / za red. O. A. Dubaseniuk. - Zhytomyr : Vyd-vo ZhDU im. I. Franka, 2012. - 284 s.

\section{Миньковыч Б. А. Развитие креативного мышления будуцего учителя информатики средствами информационно-коммуникационных технологий.}

В статье анализируется состояние развития креативного мыиления будущих учителей информатики. Рассмотрено влияние инноваџионных информаџионно-коммуникаџионных технологий на успешность творческого развития и саморазвития учителя. Раскрыта сущность понятия "креативность", его основнье признаки, значение развития креативности будущего учителя информатики в практической деятельности, опыт подготовки учителя к использованию ИКТ в старшей школе.

Ключевые слова: креативность, креативное мыиление, инновации, информационно-коммуникационнье технологии.

\section{Minkovych B. A. The Development of Creative Thinking of the Future Teacher of Computer Science by Means of Information and Communication Technologies.}

A teacher should have the ability of creative thinking and innovation activity, autonomy and non-standard decisions, intellectual competence. The quality of general secondary education system depends on the teacher. The creative personality of a teacher, in particular the teacher of informatics, should be characterized by a constant search for optimal, original solutions of the tasks, creative thinking, the ability to see the pedagogical problem and to find the ways of its solution, creative fantasy, developed imagination, high level of general culture, high level of moral consciousness. The analysis of the experience of higher education instructors and our own experience argues that heuristic methods that actively stimulate the development of the teacher's creative potential and promote the development of their creative qualities should be used to develop the creative abilities of future teachers of informatics. The results of the study indicate that most teachers of informatics are at the reproductive level of creativity. The use of modern information and communication technologies and teaching methods in the process of studying the course of computer science; taking into account the changes taking place in the modern information society and taking into account foreign experience promotes the development of creative thinking of the future teacher of informatics.

Key words: creativity, creative thinking, innovations. 